\title{
A Spinster with a Twist: The Amateur Sleuth and Perspectives on Ageing and Gender in the Sunday Philosophy Club Series
}

\section{Introduction}

It is almost a hundred and fifty years since the American writer Anna Katharine Green (1846 -1935) wrote The Leavenworth Case (1878), the first of a series of detective novels featuring the amateur sleuth Amelia Butterworth. Green's character is considered to be the literary mother of all the spinster detectives of the socalled Golden Age of detective fiction, among them the celebrated Miss Jane Marple. Since then, a flock of amateur sleuths has populated the pages of detective fiction, displaying, among other things, how the status of women has evolved alongside the genre. As Kathleen Klein notes,

\footnotetext{
The stereotype of the woman detective - the elderly spinster, the naive young woman, the bored housewife - has never been easy to sustain. The contemporary crop of detecting women is not only a critique of those earlier stereotypes and a promise for women's roles in a more open future society but also a challenge to the limitations of women's current roles. $(1995,12)$
}

This paper contends that Alexander McCall Smith's Sunday Philosophy Club series provides yet another example of such evolution. McCall Smith's unusual detective stories, while broadly following the conventions of classic Anglo-American detective fiction, propose a gentler alternative to the more cynical, violent version of the genre prominent in contemporary detective fiction. In turn, the character Isabel Dalhousie, a philosopher and amateur sleuth, initially seems to be a classic Marple-like detective who unexpectedly ends up making different life choices, becoming a wife and mother in her mid-forties - thereby subverting negative stereotypes about women and ageing.

Alexander McCall Smith (1948-) was born in Bulawayo, in the former British colony of Southern Rhodesia (present-day Zimbabwe). One of the most prolific authors in contemporary fiction in English, he was a professor of Medical Law at the University of Edinburgh and a member of the UNESCO International Bioethics Commission, while serving as vice-chairman of the UK's Human Genetics Commission and sitting on a number of other bio-ethics committees. In 2005 he 
abandoned all his professional activities to dedicate himself fully to literature, which he calls "a cathartic experience" (McCall Smith 2007). McCall Smith has written more than a hundred volumes (most of them after the age of fifty), including novels, children's books, short stories, non-fiction, and several series. Among the latter are the celebrated No. 1 Ladies' Detective Agency novels, featuring beloved Precious Ramotswe, the 44 Scotland Street series, the Von Igelfeld books, the Corduroy Mansions series, and the Sunday Philosophy Club. This article concentrates on the last of these, which features the middle-aged philosopher and amateur detective Isabel Dalhousie, whose deep philosophical interrogations and intensely human dimension shed light on women's middle age while interrogating fundamental notions about ethical living and life at large.

To my knowledge, only one scholarly article (Domínguez-Rué 2018) has analysed Isabel Dalhousie's character from the perspective of ageing studies. Taking feminist theory, ageing studies, and detective fiction genre criticism as a methodological basis for my analysis, and using examples from the above-mentioned series by McCall Smith to substantiate my argument, this paper will try to elucidate whether these novels (in particular, and literature in general) might help to raise awareness about negative stereotypes of ageing and gender to a massive audience of female (and male) readers. In order to provide an illustration of such view, examples will be provided from the first, sixth, and eleventh novels in the series - The Sunday Philosophy Club (2004), The Lost Art of Gratitude (2009), and A Distant View of Everything (2017) - with the aim of offering a brief but comprehensive overview of the issue examined. My aim is to reveal the extent to which Dalhousie and the series as a whole can become a catalyst for change that not only offers an innovative version of the amateur spinster detective character, but also vindicates the empowering possibilities involved in embracing a more positive view of women and ageing-into-the-middle-age.

\section{The Spinster Detective}

According to Jennifer Weiss, it is usually accepted that a detective story should contain the following elements: 1) a detective figure; 2) a crime that seems difficult or impossible to solve; 3) an investigation; 4) a final explanation of what happened and, finally; 5) the arrest of the criminal. The clue is a further key element of the detective story, the unit par excellence in the genre (Weiss 2014). Similarly, as Cheri L. Ross contends, the conventions that make up a detective story are usually the following: 
(1) commission of a baffling crime by an unknown person; (2) a professional male detective who may need assistance in solving the crime from an amateur (also male); (3) the arrest of an innocent person; (4) use of devices such as locked rooms and red herrings; (5) a suspenseful narrative; (6) emphasis on observation and deduction; (7) a visit to the scene of the crime; (8) identification of the criminal, who is usually the least likely suspect; and (9) a credible solution based on information in the fiction itself (1991, 77 [emphasis mine]).

Before Anna Katharine Green's creation of the first spinster detective in fiction, professional detectives were men - Auguste Dupin, the fictional character created by Edgar Allan Poe, made his first appearance in Poe's The Murders in the Rue Morgue (1841) and is widely considered the first detective character in English literature (Poe 1985). Women were usually either villains or victims - not amateur sleuths, and rarely even main characters. The arrival of Green's Amelia Butterworth inaugurates a procession of middle-aged spinsters and "old maids" who missed their chance (willingly or not) to be eligible in the marriage market and who will later populate the genre: feminine without being sexually desirable and curious without being dangerously intelligent - that is, harmless and invisible in their superannuation.

The female detective gained great popularity at the onset of the twentieth century, with fictional characters like the illustrious Miss Marple (Craig and Cadogan 1986). According to Linn Style (2012), writers of the time created female characters who became detectives either to restore the damaged reputation of a friend or relative, or because mere coincidence had put them in the wrong place at the wrong time - in any case, not because of their own will. Still, these characters gave voice to a group of women at that period who were trying to find a space in a male-dominated society that considered them superfluous in their spinsterhood. As Style writes, "through the mouth of an old maid, [writers] were able to get away with social criticism that from a younger, more attractive woman would have been perceived as provocative" $(2012,7)$. Indeed, younger female sleuths such as Dorothy Sayers' Harriet Vane, Agatha Christie's Tuppence Beresford, or Anne Perry's Charlotte Pitt (a more contemporary author, although the setting of the novels is Victorian) are married off by their creators to their professional male partners in crime - the reader assumes, to preserve their respectability while doing "an unsuitable job for a woman", to quote P. D. James' 1972 novel featuring professional detective Cordelia Gray (2010). In contrast to these younger, easily marriageable women, the middle-aged spinster was considered a grotesque anomaly, having lost her chances to be eligible for marriage and thus to occupy her "natural" space in the domestic sphere (Lepine 2007). As Anna Lepine observes, "the spinster of a certain age becomes a ghostly presence haunting normative femininity. If she does not vanish, taking herself and her unreproductive sexuality out of sight, [she] seems to become ridiculous 
and grotesque" $(2007,36)$. However, and paradoxically, it is her discretion and her sexual (and social) invisibility what essentially confers spinsters their greatest power of detection, as their harmless appearance and their purported inferiority allow them to gain access to spaces and information barred to the more authoritative and aggressive-looking male professional detective, as Lepine remarks: "as an unmarried woman, she was an exile in relation to the idea of home but, as a woman, she possessed innate homemaking abilities. Consequently, she was able to infiltrate areas of the home inaccessible even to the ideal domestic woman” $(2007,12)$.

Despite the social and political accomplishments achieved by feminism in the twentieth century, both in fiction and in fact, researchers focused on ageing and gender agree that negative stereotypes of ageing affect women more than they do men, since women are still socially valued primarily for their beauty (see, for example, Woodward 1999; Wolf 2002). Jacquelyn Zita asks herself a significant question in relation to the analysis of the novels that concern us here: "Age affects both sexes, but why are the more odious meanings of ageism unevenly dumped on the female body?” $(1997,108)$ The answer seems to lie in the patriarchal status of woman as reproductive and as object of desire, which has culturally relegated mature women to gradual invisibility, especially in the light of the "double standard of ageing" described by Susan Sontag:

The double standard of ageing shows up most brutally in the conventions of sexual feeling, which presuppose a disparity between men and women that operates permanently to women's disadvantage [...] Women become sexually ineligible much earlier than men do [...]. For most women, ageing means a humiliating process of gradual sexual disqualification. Since women are considered maximally eligible in early youth, after which their sexual value drops steadily, even young women feel themselves in a desperate race against the calendar. They are old as soon as they are no longer very young. $(1997,20)$

Zita similarly reveals the mechanisms of patriarchy to be accountable for the social invisibility of mature women, which she explains as follows:

The sensuous confirmation needs of heteromasculinity read the aged female as a negative sign. She is gladly left out of the picture, except for benign grandmother roles, gladly forgotten, and gladly replaced by younger females, whose bodies match the Platonized ideal of unchanging and "unageing" female beauty, captivating the psychic needs of a culturally constructed heteromasculinity. The crone becomes spectral, an appearance without substance. $(1997,108)$

In light of these views, the ageing model determined by chronological time and the youth cult has been reinforced by patriarchal discourses, perpetuating the invisibility of mature women - despite a number of studies that reveal this peri- 
od as one of flourishing and new opportunities (see, for example, Heilbrun 1988, 1990, 1997; Banner 1992; Pearsall 1997; Gullette 1997). Such discourse thereby precludes more positive discourses on gendered ageing. In short, despite our regular interaction with middle-aged women who live happy and fulfilling lives, and fictional accounts that confirm this, many women still perceive the accumulation of birthdays as a gradual loss. Such loss is often not caused by any biological process, but by self-perception and by the degree to which women have either internalised or rejected the double standard of ageing, as Sontag has observed:

Ageing is much more a social judgement than a biological eventuality. Far more extensive than the hard sense of loss suffered during menopause [...] is the depression about ageing, which may not be set off by any real event in a woman's life, but in a recurrent state of "possession" of her imagination, ordained by society - that is, ordained by the way this society limits how women feel free to imagine themselves. $(1997,21)$

In order to counteract pervasive cultural discourses about women and middle age, I argue that detective fiction as a popular cultural product and a re-examination of the figure of the spinster detective in particular may contribute to interrogating the decline narrative and counterbalancing the predominantly negative correlation between womanhood and maturity. In her 1979 work Reinventing Womanhood, the feminist theorist Carolyn Heilbrun had already remarked that existing stereotypes of spinster detectives needed a profound reassessment: even before her creation of the Columbia professor and amateur sleuth Kate Fansler under the pseudonym of Amanda Cross, Heilbrun wrote that "whether they have been left on the shelf or have climbed upon it voluntarily, they [spinster detectives] turn their solitude into power and their superfluity into freedom" $(1979,96)$.

Isabel Dalhousie provides a good example of the constant transformation of the character - in Isabel's case, not into independence and self-determination, since she is already a financially independent professional, but rather out of the label "spinster" by marrying a much younger man and having two children well after the period of maximum eligibility as a woman according to conventional social standards. In this sense, Dalhousie embodies a different image of a detective, one that does not conform either to the genre's conventions of the character or to the socially ascribed roles expected of a woman her age.

In her comprehensive volume on feminism and the detective novel, Murder by the Book, Sally Munt contends that the 1970s and, in particular, the 1980s witnessed the ascendancy of a particular type of female crime writer and female detective, "typically white, middle class and often holding a $\mathrm{PhD}$ from a wellknown university" (2004, 33). According to Munt, the rise of academic detectives and campus murder stories follow the settings of the British and American tra- 
dition of crime fiction and use education as a way to social improvement and as a means to solve the mystery. Dalhousie could be counted among this group of highly-educated amateur detectives, holding degrees from Cambridge and Georgetown and using her own private code of "moral proximity" as a way of solving mysteries and living ethically while doing so. Despite the character's privileged status, and as Anne Cranny-Francis acknowledges, a female character performing a traditionally male role transforms both such role and also the plot itself. Therefore, a female detective character who is to be credible both as a detective and as a woman must necessarily be "more than just an honorary male" and therefore "requires a radical reassessment of the characterisation of the detective and the narrative” (Cranny-Francis 1990, 143). The following section will analyse the ways in which the character of Isabel Dalhousie provides a revision of the social and cultural prejudices attached to mature women, while at the same time re-examining the conventions of the genre.

\section{Isabel Dalhousie, a Spinster with a Twist}

Sensitive, empathetic, well-mannered, curious and sharp-eyed, Isabel works as editor of the Review of Applied Ethics while also investigating the mysterious situations she encounters in her native Edinburgh, showing her inherent humanity and compassionate nature while doing so. It is her growing reputation as compassionate person - "you seem so sympathetic" (McCall Smith 2009, 65) - rather than her detecting skills that typically bring her into contact with the conflict: "the reason I thought I should speak to you is because I know you have helped various people" (McCall Smith 2009, 66). In this sense, she conforms to the paradigm of the amateur sleuth, driven to detective work by coincidence or at the request of someone in need, rather than by inquisitiveness or professional interest. The very act of becoming involved in a situation that most of the time does not concern her is triggered less by curiosity than by the moral obligation to do what she thinks is correct: "It was moral proximity again: this man standing before her was not a moral stranger to her - he was asking her for help and she could not turn him away. She simply could not” (McCall Smith 2009, 137). As Isabel explains to herself in the first novel of the series, The Sunday Philosophy Club, "there was no reason why she should become involved in the affairs of others, but she seemed to be irresistibly drawn into them. And every time that she did it, it was because she imagined that there was a moral claim on her" (McCall Smith 2004,76 ). The reason for her involvement in cases is her very own private theory of moral proximity, which she describes as "the basis of those obligations that came into existence when we found ourselves close enough to others to be 
able to witness or feel their needs, or when we were in some other way linked to their plight” (McCall Smith 2017, 160 -161). As the character explains,

\begin{abstract}
If she had never studied philosophy and never wrestled with issues of our moral obligation to others, she would not have had to act at all. But she had done, and she could not unlearn everything she had acquired in Cambridge and Georgetown; nor could she forget that she was a citizen of Edinburgh, of the city of David Hume. I am obliged to act, she thought; by geographical propinquity, and by the mere fact of being human, I am obliged to act. (McCall Smith 2009, 117)
\end{abstract}

The inherent philanthropy of Isabel's investigations - devoid of financial or professional purposes - aligns the character with classic Marple-like spinsters. In Isabel's case, however, her ethical behaviour is further grounded by a thorough professional training in philosophy. Despite that, however, The Sunday Philosophy Club series is lacking some of the characteristics described by Weiss and Ross in the previous section: the amateur sleuth is a single, middle-aged woman, and the male professional detective in completely absent in this case. What is more, no one is ever arrested; the police do not even feature, much less intervene in the plot. To make the series and its detective even more unconventional, the ending of the Isabel Dalhousie novels offers an unexpected solution (and often no solution) to the initial conflict - that is, there was actually no murder, or no theft. Even when an act punishable by law has been committed, the elucidation of the initial mystery does not involve arresting the offender. For example, in The Sunday Philosophy Club, Isabel discovers that the young man who allegedly fell to his death from a balcony after a concert in the Usher Hall in Edinburgh did not actually fall but was accidentally pushed by a friend. However, Isabel decides not to report it as there is no clear evidence to incriminate him apart from his confession, and she believes there is no point in destroying the future of another young man who will anyway carry the weight of remorse for his whole life. Similarly, in The Forgotten Affairs of Youth (2011), Isabel helps Jane, a visiting scholar who was adopted and sent to Australia as a child, to trace her family origins and find her biological father. After a number of investigations in old university records and a series of interviews with people who had known Jane's mother at the time, a man is eventually discovered who had been having a relationship with Jane's mother at the time when she got pregnant, and who is very likely to be Jane's father. When Isabel learns from his wife that this man cannot be Jane's biological father because he is actually sterile, Jane asks her not to reveal that truth to him, as both are very happy about having found each other and this acquaintance has filled an emotional gap in the lives of both. Despite her moral doubts about letting an age- 
ing man believe a lie, Isabel decides that their newly-found joy and the emerging warmth they feel for each other is more important than DNA.

The example from a later novel, in which Isabel offers support to a younger colleague, reveals another feature of contemporary female detective novels, as well as in feminist explorations of middle age. In contrast to traditional patriarchal discourse, which emphasises a tension between (surrogate) mothers and daughters and competition among women in the marriage market, fiction that features amateur sleuths as well as middle-aged women reveals the great value such characters confer to their relationships with other women. As opposed to the cultural disqualification of women through a process of gradual downgrading and invisibility as they age, scholars like Heilbrun (1988, 1997) have explored the possibilities that the onset of middle age can offer them, among which is the fulfilment of friendship with other women. Similarly, Shulamit Reinharz argues that “in contrast with men, women in general don't begin to challenge the politics of their lives until later [. . .] during their youth women are most valued for their full potential as workers, wives, sex partners and child bearers" (1997, 80 - 81). Women of all generations need each other for friendship, support, and encouragement, in a mutually enriching relationship that is not necessarily restricted to biological motherhood. As Reinharz argues,

The severing of bonds may actually reflect a male definition of radical activity, flowing from the boy's breaking the tie with the father as the means of liberation. By contrast, what is radical for women is the ability to bond with women, to forge sisterhood with other women rather than separateness. $(1997,81)$

Besides her altruistic (if sometimes not very professional) investigations, the role of Isabel's female network can be observed in her daily relationship with the members of her family, biological or surrogate. References to Isabel's dead mother appear in every novel as a faint but constant presence, especially when memories of her are triggered by familiar places in Edinburgh, or when she reflects about what her mother would do or say in a certain situation:

Her mother - her sainted American mother - had died when Isabel was eleven, and the memories were fading. Months and years blurred into one another, and Isabel's mental picture of the face that looked down at her as she was tucked into bed at night was vague now. (McCall Smith 2004, 16)

Even when "her sainted American mother" is revealed to have had an affair with another man, Isabel takes the news as a chance to reassess her idealised view, and to see her as a human being, without bitterness or regret. 
Apart from her absent biological mother - and maybe because of that absence - Isabel's affection for her housekeeper Grace provides a good example of female bonding within a surrogate family. Grace, another "spinster lady of a certain age” to quote Agatha Christie's The Murder at the Vicarage (2010, 41), is a truly lovable character who nevertheless remains stern in her disposition and inflexible in her (sometimes unconventional) beliefs. Even if her strong personality and her often peculiar views often make her difficult to live with, and even if Grace is Isabel's employee, Isabel tries to feel thankful for the life she has and fortunate for having Grace in her life: "Gratitude was a lost art, she felt. People accepted things, took them as their right, and had forgotten how to give proper thanks" (McCall Smith 2009, 158). She constantly reminds herself not to take advantage of her more privileged position to be harsh to her housekeeper and remains aware that, despite her rather unconventional ways, Grace ultimately acts with Isabel's and her family's wellbeing in mind: “There were many other ways in which Isabel's position was so much more fortunate than her housekeeper's, and the cumulative effect of these was that Grace was forgiven: she could be as demanding or as sniffy as she liked - she was forgiven" (McCall Smith 2017, 74).

Throughout the series, Grace remains a prominent character, and the reader comes to regard her as a member of Isabel's growing family, as is Cat, Isabel's problematic niece. Isabel helps Cat in her delicatessen and constantly tries to brave her sometimes thoughtless actions and unfortunate choice of men. A clear example of the ups and downs in Isabel's relationship with Cat takes place in The Sunday Philosophy Club (2004), when Isabel, suspicious from the beginning that her niece's fiancé Toby is not the most suitable man for her, follows him in the street and accidentally finds out that he is having a relationship with another woman. Even though it is imperative that Cat should know as soon as possible that Toby is being unfaithful, Isabel is conscious that the information will deeply hurt her feelings, and that it is morally inappropriate to intervene in her niece's relationship. Isabel - a philosopher by profession and a philanthropist by vocation - is fully aware that "it was easy, terribly easy, to become with time a middle-aged spinster with a sharp tongue" (McCall Smith 2004, 142). However, and even if she has tried to convince herself that Cat is old enough and should deal with her relationship herself, she cannot avoid revealing her secret when Cat announces her engagement to Toby:

She had not meant to say it - she knew it was wrong - and yet it had come out, as if spoken by somebody else. Immediately she felt miserable, thinking: So are wrongs committed, just like that, without thinking. The doing of wrong was not a hard thing, preceded by careful 
thought; it was a casual thing, done so easily. That was Hannah Arendt's insight, was it not? The pure banality of evil. Only good is heroic. (McCall Smith 2004, 196)

Despite Cat's often spiteful and inconsiderate behaviour and her unwillingness to listen to any advice, Isabel remains affectionate towards her and tries to understand her feelings, prompting herself to evoke Arendt's view and make the "heroic" effort of not losing patience with Cat. In Isabel's view, the only worthy man on the list of Cat's former partners is Jamie, a young bassoonist with whom Isabel develops a friendship initially based on their mutual love for music. McCall Smith is an amateur bassoonist himself, having founded The Really Terrible Orchestra with the businessman Peter Stevenson in 1995: both the orchestra and Stevenson appear in the series. Despite the fact that Jamie is already presented as Cat's ex-boyfriend in the first novel, he and Isabel continue to meet occasionally, and he becomes involved in the investigation at Isabel's request. The fact that Jamie is fourteen years Isabel's junior, coupled with his former relationship with Cat, features in the novel as a strong impediment for the development of a relationship between them, as Isabel is fully aware of her status as single and middle-aged:

Barely had Jamie left the house than a thought occurred to Isabel. It almost sent her running after him to tell him about it, but she desisted. It was not at all that late, and several neighbours walked their dogs along the street at that hour. She did not wish to be seen running after young men, in the street at least (though the metaphorical context would be as bad.) (McCall Smith 2004, 153)

The character's descriptions and actions make it obvious to the reader that Isabel is not an overtly subversive and rebellious woman, but actually very conscious of her age and the sociocultural expectations associated with it. Besides her awareness of the cultural discourse around women and ageing, the novels often include instances where others define Isabel's proper place in normative womanhood by highlighting not only the evidence of her abnormality as a single middle-aged woman but the "futility" of her condition:

"Don’t tell me my job, Isabel."

"Ms. Dalhousie, actually."

“Oh yes, Ms. Dalhousie. Spinster of this parish.” He paused. "Surprising, that. You being an attractive woman, sexy if I may say so.” ...

"You have some beautiful things", he said. "Money?"

(McCall Smith 2004, 36-37)

Kathleen Woodward $(1991,1999)$ has written extensively about the pervasive gerontophobia with which Western culture has endowed representations of old age. 
When reflecting upon the feelings of anxiety that ageing brings about, she argues that "fear of age is not a strictly 'personal' problem. Our culture's representations of ageing are predominantly negative" $(1999,4)$. These negative images affect women much more than they do men: being relegated to cultural invisibility once they reach middle age, mature women's success is largely measured in terms of how closely they can approach the appearance of a younger woman (Woodward 1999, 159). Being fully conscious of these cultural discourses and well knowing what her "proper place" is as a woman in her early forties, Isabel cannot help feeling uneasy when she makes her investigations accompanied by Jamie, not yet thirty, and is aware that people will make judgements about their possible relationship: "He's wondering what the relationship is. Toy boy, probably; or so he thinks. But even if that were the case, why should he be surprised? It was common enough these days" (McCall Smith 2004, 166). Despite her reflection that a growing number of women nowadays have much younger partners, and recalling Woodward's words, pervading prejudices against middle-aged women unconsciously lead to such a perception of oneself and one's place in the world: "She was anxious in the pub, waiting for Jamie. It was a masculine place, at least at that hour, and she felt ill at ease. Women could go to pubs by themselves, of course, but she nonetheless felt out of place" (McCall Smith 2004, 161).

Isabel will in time start a relationship with Jamie and unexpectedly become pregnant, events that occasionally make her relationship with Cat tense, but do not diminish Isabel's affection for her niece. Cat's new choice of fiancé in The Lost Art of Gratitude (2009) is a tightrope-walking stuntman whose appearance and personality make him look even less suitable for Cat than her previous boyfriends. Moreover, Isabel suspects that Cat has rushed into engagement out of spite after learning that she and Jamie are themselves about to be married. Despite Isabel's frequent reflections about the appropriateness of her relationship with Jamie and two occasions in which she believes Jamie could be taking up with a younger woman, her maternity and her marriage to Jamie prove to be happy and harmonious, revealing the change in available roles for women in their midlife, as well as the internal and external conflicts they may face.

In A Distant View of Everything (2017), Isabel's help and detecting talents are required by an acquaintance, the vocational match-maker Bea Shandon. Isabel is asked to investigate the reputation of a bachelor who has been dating one of Bea's female friends, the very promising but somewhat dubious surgeon Tony MacUspaig. Despite the fact that Isabel's character has been shown to deviate from ageist and sexist conventions, the novel is well aware of the pervading presence of negative stereotypes attached to women at midlife. The novel presents the reader with the fact that being single is still regarded by many 
women as a degrading and undesirable status, mainly through the accounts of Bea Shandon and her match-making: in her words, "there are far more women than men looking for someone” (McCall Smith 2017, 51). At Isabel's perplexity about men's eligibility as potential partners despite her friend's doubts about their suitability, Bea replies that "he was a man and there were always, always women who would take on a spare man, even if he was completely porcine” (McCall Smith 2017, 52). As she explains, "if you're a man and you're wanting to meet somebody, then you're absolutely guaranteed to find somebody. Guaranteed. The only reason you won't is if you're utterly impossible - which few men are" (McCall Smith 2017, 51). Bea's comments, the reader infers, reveal that the figure of the middle-aged spinster with all its adjoining patriarchal weight of negativity is still a fearful destiny to be avoided at all cost, as if it were a sign of personal failure: "They have to join the queue. They find out that for each spare man there are ten or twelve, maybe more, contenders. Widows, divorcees - there are hundreds of them milling about, all desperate to get one of the handful of spare men available" (McCall Smith 2017, 52).

Nonetheless, in A Distant View of Everything, Isabel is in her late forties, has married Jamie, and has recently given birth to their second child: those events have transformed her, according the conventions of the genre, from being aligned with the Amelia Butterworths and Jane Marples to falling into the category of the Harriet Vanes and Tuppence Beresfords - only twenty years older than the latter group. Rather than guaranteeing Isabel's respectability in her unusual occupation as amateur detective, as is the case of Vane or Beresford, or culturally inscribing her "success" in life as a married woman and thus bringing her back to normative femininity, the character shows the changing mores of changing times, as well as providing a more contemporary alternative to the available roles of the character in the genre of detective fiction. McCall Smith's fiction thus constitutes a mirror for interrogating existing prejudices against gendered ageing, providing new available social and cultural roles for mature women.

\section{Conclusions}

The higher life expectancy and general improvement of the status of women in the Western world, together with political, cultural, and socio-economic change, have granted women longer, healthier and more independent lives. The love lives of celebrities like Madonna or Jennifer Lopez offer a public (if not altogether truthful) picture of women's choice to start a relationship with a much younger man, a practice that has become more common in recent decades, but which had 
been traditionally considered inappropriate and often ridiculous, in contrast with the widely accepted notion that men may marry considerably younger women. Scholars have noted that female detectives - even during the Golden Age of the 1920 s and the 1930 s - have traditionally represented patriarchal prejudices while revealing the limitation of women's roles: however, it has taken time for them to deconstruct these roles (Slung 1977; Mann 1981). Detective fiction of the last decades, as well as other types of contemporary popular fiction, has begun to use the genre with a political agenda in mind to explore and interrogate the role of women and the cultural construction of women's lives. As Jessica Mann has asserted, "the modern detective story lifts the mask of polite society, the veil of incomprehension, to reveal something from which one might prefer to avert one's eyes" (1981, 239). In this sense, The Sunday Philosophy Club series and the character of Isabel Dalhousie unmask persistently negative cultural discourses about women and ageing and existing prejudices against middle-aged women, while revealing that, in fiction as well as fact, new choices are actually available for women out and away from those stereotypes.

As Lois Marchino has observed, "popular culture often provides clues to fundamental social issues, and one of the most striking current developments in genre fiction is the use of the mystery novel to challenge the traditional roles of women" $(1989,89)$. The coherent "I" that prevailed until the twentieth century has been subject to innumerable fractures, dislocations, and ambiguities, while the unified notion of self, especially since Postmodernism, has been replaced by a multiplicity of fluid subjectivities. Differing from French feminist theories, which mainly placed the essence of the female self on the body, Sidonie Smith (1990, 15) argues that gendered identity, being culturally constructed rather than biological, is also subject to constant change. If that is true of gender, it is also true of age. While women may still be prisoners of cultural ideas of gender, the examination of detective fiction that deconstructs stereotypes of gender normativity allows women to interrogate their own subjectivities in middle age (and beyond) and create perhaps equally unstable and fluid but less constrained identities for themselves.

\section{Works cited}

Banner, Lois W. In Full Flower: Ageing, Women, Power and Sexuality. New York: Alfred Knopf, 1992.

Craig, Patricia, and Mary Cadogan. The Lady Investigates. Oxford: Oxford University Press, 1986. 
Cranny-Francis, Anne. Feminist Fiction: Feminist Uses of Generic Fiction. Cambridge: Polity, 1990.

Christie, Agatha. Miss Marple 3-Book Collection 1: The Murder at the Vicarage, The Body in the Library, The Moving Finger. London: HarperCollins, 2010.

Domínguez-Rué, Emma. "The Art of Doing Good: Aging, Creativity and Wisdom in the Isabel Dalhousie Novels." Journal of Aging Studies 44 (2018): 22 - 27.

Green, Anna Katharine. The Leavenworth Case. London: Penguin Classics, 2010.

Gullette, Margaret Morganroth. Aged by Culture. Chicago, IL: University of Chicago Press, 1997.

Heilbrun, Carolyn. Reinventing Womanhood. New York and London: Norton, 1979.

Heilbrun, Carolyn. Hamlet's Mother and Other Women. New York: Ballantine Books, 1990.

Heilbrun, Carolyn. The Last Gift of Time: Life Beyond Sixty. New York: Ballantine Books, 1997.

Heilbrun, Carolyn. Writing a Woman's Life. New York: Ballantine Books, 1998.

James, P. D. An Unsuitable Job for a Woman. London: Faber \& Faber, 2010.

Klein, Kathleen Gregory. Ed. Women Times Three: Writers, Detectives, Readers. Bowling Green, OH: Bowling Green University Popular Press, 1995.

Lepine, Anna. The Old Maid in the Garret: Representations of the Spinster in Victorian Culture (Dissertation). https://ruor.uottawa.ca/bitstream/10393/29443/1/NR32409.PDF. Ottawa: University of Ottawa, 2007 (22 November 2019).

Mann, Jessica. Deadlier Than the Male. New York: Macmillan, 1981.

Marchino, Lois. "The Female Sleuth in Academe." Journal of Popular Culture 23.3 (1989): 89-100.

McCall Smith, Alexander. The Sunday Philosophy Club. London: Abacus, 2004.

McCall Smith, Alexander. Interview: The Scottish Author Talks us from Africa to the Streets of Edinburgh. https://strandmag.com/the-magazine/interviews/alexander-mccall-smith/. The Strand Magazine, 2007 (22 November 2019).

McCall Smith, Alexander. The Lost Art of Gratitude. London: Abacus, 2009.

McCall Smith, Alexander. The Forgotten Affairs of Youth. London: Abacus, 2011.

McCall Smith, Alexander. A Distant View of Everything. London: Abacus, 2017.

Munt, Sally R. Murder by the Book? Feminism and the Crime Novel. New York and London: Routledge, 2004.

Pearsall, Marilyn. Ed. The Other Within Us: Feminist Explorations of Women and Aging. Boulder, CO: Westview, 1997.

Poe, Edgar Allan. Tales of Mystery and Imagination. New York: Oxford's World's Classics, 1985.

Reinharz, Shulamit. "Friends or Foes: Gerontological and Feminist Theory." The Other Within Us: Feminist Explorations of Women and Aging. Ed. Marilyn Pearsall. Boulder, CO: Westview, 1997. 73-94.

Ross, Cheri L. “The First Feminist Detective: Anna Katharine Green's Amelia Butterworth.” Journal of Popular Culture 25.2 (1991): 77-86.

Slung, Michele. Crime on Her Mind: Fifteen Stories of Female Sleuths from the Victorian Era to the Forties. Harmondsworth: Penguin, 1977.

Smith, Sidonie. "Self, Subject, and Resistance: Marginalities and Twentieth-Century Autobiographical Practice." Tulsa Studies in Women's Literature 9.1 (1990): 11-24.

Sontag, Susan. "The Double Standard of Aging." The Other Within Us: Feminist Explorations of Women and Aging. Ed. Marilyn Pearsall. Boulder, CO: Westview, 1997. 19-24. 
Style, Linn. The Spinster Detective: A Comparison Between Maisie Dobbs and the Women Detectives of the Golden Age (Dissertation). http://lup.lub.lu.se/luur/download?func= downloadFile\&recordOId=3046413\&fileOId $=3048448$. Lund: University of Lund, 2012 (22 November 2019).

Weiss, Jennifer. Clue, Code, Conjure: The Epistemology of American Detective Fiction, 1814-1914 (Dissertation). https://academicworks.cuny.edu/cgi/viewcontent.cgi?article= 1125\&context=gc_etds. CUNY Academic Works, 2014 (22 November 2019).

Wolf, Naomi. The Beauty Myth: How Images of Beauty are Used Against Women. New York: HarperCollins, 2002.

Woodward, Kathleen. Ed. Aging and its Discontents: Freud and Other Fictions. Bloomington, IN: Indiana University Press, 1991.

Woodward, Kathleen. Ed. Figuring Age: Women, Bodies, Generations. Bloomington, IN: Indiana UP 1999.

Zita, Jacquelyn R. "Heresy in the Female Body: The Rhetorics of Menopause." The Other Within Us: Feminist Explorations of Women and Aging. Ed. Marilyn Pearsall. Boulder, CO: Westview, 1997. 95-112. 
